\title{
Effect of different packaging materials on quality of garlic powder
}

\author{
- S.V. Bondre, A.M. SOnKamble* and S.R. PATIL \\ Department of Horticulture, Dr. Panjabrao Deshmukh Krishi Vidyapeeth, AKOLA (M.S.) INDIA \\ Email : arvind.pdkv@gmail.com
}

*Author for Correspondence

Research chronicle : Received : 09.04.2016; Revised : 09.05.2016; Accepted : 21.05.2016

\section{SUMMARY :}

An experiment was performed in year 2014 to determine the effect of different packaging material on quality of garlic powder.Dehydrated powder of garlic cv. AGRIFOUND WHITE (G-41) was prepared by drying at $60 \pm 2{ }^{\circ} \mathrm{C}$ from well matureddisease free bulbs procured from Vegetable Research Unit, Dr. PDKV Akola, Maharashtra. Different packaging material viz., control (without packaging), polyethylene 200 gauge, polyethylene 300 gauge, aluminated foil, plastic bottle and glass bottle were used for packaging and stored under ambient condition for 120 days. The physico-chemical observations like moisture content, titrable acidity, ascorbic acid and protein content of the powder were analyzed. Also sensory evaluation of powder was carried out to judge consumer acceptability. The data obtained were analyzed using FCRD model.The packaging material aluminated foil found superior in maintaining maximum ascorbic acid $(12.47 \mathrm{mg} / 100 \mathrm{~g})$ and titrable acidity $(1.05 \%)$. Whereas glass bottle packed garlic powder registered minimum increase $(34.20 \%)$ in moisture and scored maximum (7.3) in 9 point hedonic scale for sensory evaluation. Packaging material had non-significant effect on protein content.

KEY WORDS : Garlic powder, Packaging material, Physico-chemical observations

How to cite this paper : Bondre, S.V., Sonkamble, A.M. and Patil, S.R. (2016). Effect of different packaging materials on quality of garlic powder. Internat. J. Proc. \& Post Harvest Technol., 7 (1) : 121-125. DOI: 10.15740/HAS/IJPPHT/7.1/121-125 